\title{
Scotland: Wellbeing as Performance Management
}

\begin{abstract}
Scotland was the first of the three devolved legislatures to embark on a wellbeing framework. The framework applies to all government departments and public bodies and aligns their activities by seeking improvements in 11 National Outcomes. With over 10 years of experience, it tells a strong story of how a focus on wellbeing can reorientate government by creating a shared language for public services and a sense of unity of purpose. The process also reframed the relationship between the Scottish Government and local government, with differing views on the success of this process. There are clear policy outcomes in relation to early intervention and joined-up working, however question marks remain over the extent to which the Scottish Government has reframed its role, particularly in the relationship between citizens and the state where participatory measures remain in their infancy.
\end{abstract}

Keywords Scottish Government - National Performance Framework • Public sector reform - Localism • Outcomes - Participation

The Scottish Government wants Scotland to be the best place possible to live, work, grow up and study in... As a government we recognise that economic growth is hugely important, but it must be matched by improvements in our environment, in people's quality of life, in the opportunities available to people and the public services they have access to...

J. Wallace, Wellbeing and Devolution, Wellbeing in Politics and Policy, https://doi.org/10.1007/978-3-030-02230-3_3 
As a government and as a country, the challenge this new framework sets us all is to make progress in these areas to improve wellbeing across Scotland. The new NPF belongs to all of Scotland and together we can fulfil the promise contained in it.

Nicola Sturgeon, First Minister of Scotland (Scottish Government 2018a)

\section{INTRODUCTION}

Scotland was the first jurisdiction in the UK to begin experimenting with wellbeing frameworks. Introduced by the first Scottish National Party government of Scotland in 2007, it began life as an internal tool for performance management of public services. Over a decade, it has grown in prominence and impact and has increasingly been linked to policymaking for inclusive growth. The latest iteration published June 2018, represents its full development from a performance management tool to a wellbeing framework.

\section{CONTEXT}

The Treaty of Union was established in 1707 and made the UK Parliament the legislative body for England, Ireland, Scotland and Wales. During nearly 300 years of the union of the parliaments, Scotland continued to have its own legislation and had distinct legal, church, local government and education systems. The policies determined for Scotland were not dictated by London but were rather the product of a consensus among the Scottish 'ruling' class of professionals administered by the Scottish Office and headed by a Secretary of State for Scotland (Kellas 1989).

The people of Scotland voted in favour of devolution in 1997. For the first two sessions of the Scottish Parliament (1999-2003 and 2003-2007), the Scottish Executive was run by a coalition government, formed between Scottish Labour and the Scottish Liberal Democrats. In 2007, the Scottish National Party won the election as the largest single party but governed as a minority government. They were returned to power in 2011 with a majority (69 out of 129 seats) and they are currently operating again as a minority government (2016-the present day).

The political history is important as it was this new minority government that came to power in 2007 seeking to find a new way to manage 
public services and deliver for the people of Scotland. They sought to build a collective responsibility for outcomes, measured through a new performance framework Scotland Performs. The origins of the Scottish wellbeing framework are therefore firmly in outcomes-based performance management. Its development over a decade into a wellbeing framework is due to the continued leadership shown by the small SNP cabinet, the involvement of a wider group of stakeholders and the desire for Scotland to be seen as a leading nation in public sector reform and sustainable development.

Table 2.2 identifies some of the key issues facing the wellbeing of the people of Scotland. On many international comparators Scotland performs well, particularly on community and environmental indicators. Internationally compared to the OECD regions, Scotland does not perform well on health outcomes however, and indeed is poor compared to the UK regions. The continued poor health of the nation is well-known and the subject of many public health and broader social interventions, but the outcomes remain stubbornly resistant to change.

\section{Catalysts}

The National Performance Framework (NPF) is the product of two initially disconnected sets of thinking, one political and one within the civil service (Table 3.1).

The political origins of Scotland Performs can be traced back to the first session of the Scottish Parliament. At that time, the roles and responsibilities of each parliamentary committee were being established. The Finance Committee were responsible for the budget scrutiny process, providing them with a formal role in reviewing spending proposals. They took a critical approach to the (then) Scottish Executive's budgeting process. For example in their report on the draft budget Investing in You in 2000, they argued:

Often, the targets that are contained in the document do not match the level of detail in the budgetary information. We have concerns that there is poor linkage between the overarching priorities and the individual targets: it is often not clear how the implementation of individual, administrative targets will underpin the achievement of the high-level policy priority or how increased funding in a certain area will lead to a specific target being achieved. (Scottish Parliament Finance Committee 2000, para. 30) 
Table 3.1 Timeline for the development of the Scottish wellbeing framework

Scottish Parliament re-established 1999

Finance Committee report on Cross-cutting Expenditure on Deprivation 2006 recommends local and national outcomes

Minority SNP government elected

Scotland National Performance Framework established

Carnegie Roundtable on Measuring Economic Performance and Social Progress

reports

Oxfam Humankind Index published

2012

Referendum held on Scottish Independence

Community Empowerment (Scotland) Act passed

Consultation on National Outcomes held

Scotland becomes a founding member of the international Group of Wellbeing

Economy Governments

National Outcomes laid before Scottish Parliament

2018

New National Performance Framework published

2018

Source Original

This criticism of input budgeting and targets continued through the Finance Committee meetings of Sessions 1 (1999-2003) and 2 (20032007). In the 2002-2003 Draft Budget, for example, there were around 400 targets. The Committee's report on Cross-cutting Expenditure on Deprivation raised concerns about the impact on local government of ring-fenced funding agreements and a lack of strategic direction, leading to silo-based working and a lack of integration and innovation at a local level (2007). They found 10 different funding streams spread over five departments and agencies which were regarded as specifically targeting areas of deprivation. They concluded: 'Councils and their partners should agree their intended outcomes and the steps they will take to ensure these are delivered and seek approval from the Scottish Executive as part of their contribution to achieving agreed national outcomes' (2007, para. 15). In this report we can see the origins of the Scottish approach to outcomes which developed later into the wellbeing framework called Scotland Performs. By the time of this inquiry, the Deputy Convenor was John Swinney MSP, who would become Finance Minister when the Scottish National Party came to power a year later in 2007.

During the same time period, parallel but unconnected conversations were taking place among the senior civil service. Sir John Elvidge (Permanent Secretary of the Scottish Government 2003-2010) was key 
to this process and reviewed outcomes on education, health, poverty and productivity with senior civil servants. Together they concluded that silobased policies were not tackling the underlying factors that were holding back social progress. These conversations were cascaded through the Scottish Government management structure, asking people at all levels to consider the conundrum of how an organisation could be essentially good at meeting its targets (measured against the Programme for Government commitments) but fail to make progress against broader measures of outcomes. The conversation was influenced by an increasing awareness of the limits of New Public Management, in particular, the incremental change it encourages as opposed to ambitions for more transformative approaches.

These two threads came together following the election of the Scottish National Party as a minority government. Their manifesto for the 2007 election contained a commitment to outcomes-based performance frameworks, inspired by a visit from the Governor of the Commonwealth of Virginia, Tim Kaine, and his senior officials, who had implemented a framework called Virginia Performs. Virginia Performs is a performance leadership and accountability system within state government. It begins with a vision for Virginia's future: responsible economic growth, an enviable quality of life, good government, and a welleducated citizenry prepared to lead successful lives and to be engaged in shaping the future of the Commonwealth (Wallace 2013). The originators of the Scottish scheme cite Virginia Performs as the inspiration, though it is likely that they were also influenced by other international schemes such as Measuring Australia's Progress. What is clear however is that the original aims were to improve public services through better measurement, rather than a focus on sustainable development or belief in the importance of moving away from GDP as the sole measure of social progress (though these have emerged subsequently).

As a minority government, rather than a coalition, the number of Cabinet posts from 2007 has been smaller than in either of the preceding governments of Scotland. This smaller structure provided a further incentive to change the dominant, Westminster-based, model of Ministerial responsibilities to create a system of collective responsibility for outcomes (Elvidge 2011). This approach became the cornerstone of the Scottish Model of Government, where government is perceived as a single entity, managed through: 
- An outcomes-based approach to delivering the objectives of government

- A single statement of purpose elaborated into a supporting structure of a small number of broad objectives and a larger, but still limited number of measurable national outcomes

- A system for tracking performance against outcomes and reporting it transparently and accessibly

- Single leadership roles controlling each of the political and Civil Service pillars of government, supported by small senior teams

- Understandings of the roles of the members of the senior political and Civil Service teams which give primacy to contributing to the collective objectives of the team (Elvidge 2011).

From the outside, these changes appeared sudden and radical, but from inside the civil service they were the logical conclusion of an internal conversation that had taken place over many months.

The first NPF was published in 2007 and consisted of four layers: a purpose statement; seven Purpose Targets (economic growth, productivity, participation, population, solidarity, cohesion and sustainability; measured by 11 indicators); 15 National Outcomes; and 45 National Indicators. The indicators were updated in 'real time' as new data appeared on the Scotland Performs website. The communications approach mirrored that of Virginia Performs, with trends recorded as improving, maintaining or worsening. Strict criteria on statistical changes were adopted to avoid accusations of political manipulation of these judgements.

With the origins of the NPF known best in political and civil service circles, interest from outwith the Scottish Government was slow to emerge. For example, a conference held in Dundee in 2009 had the title Measuring What Matters and was hosted by the Community Development Alliance Scotland in partnership with the International Association for Community Development, the Carnegie UK Trust and the Scottish Community Development Centre, but no direct links to the Scottish Government initiative were made at that time.

The connection between the NPF and the international movement on wellbeing frameworks was first made by the Carnegie Roundtable on Measuring Scotland's Economic Performance and Social Progress. The roundtable was set up as a direct response to the recommendation of the Stiglitz-Sen-Fitoussi report that: 'At the national level, roundtables 
should be established, with the involvement of stakeholders, to identify and prioritise those indicators that carry to potential for a shared view of how social progress is happening and how it can be sustained over time' (Stiglitz et al. 2009, p. 19). The Scottish roundtable was chaired by Professor Jan Bebbington, St Andrews University and set up by the Carnegie UK Trust and the Sustainable Development Commission for Scotland. Members came from the public, private and third sectors.

The report did not initially set out to review the NPF. At the outset, only a few of the members knew of its existence. This is characteristic of the time, as even a leading textbook on social policy in Scotland gave the NPF only two mentions across 15 chapters, covering everything from inequality to environment to crime (Mooney and Scott 2012). As one roundtable participant noted, it was a rather pleasant surprise to find that Scotland already had a system that performed reasonably well against the recommendations of the Stiglitz-Sen-Fitoussi report (Wallace 2013).

Sir John Elvidge (Permanent Secretary of the Scottish Government 2003-2010) told me, that prior to the report of the roundtable, the term wellbeing was not used in relation to the NPF: 'If one reverse engineers from the content of the national performance framework, one can see there's a very broad concept of what it means to be successful nationally, it is implicit in that framework, and now we would probably use the word wellbeing as a way of summing up that breadth of vision, but we didn't at the time.' The launch of the Commission report marked an important milestone in its development, as partners from other public and third sector organisations began to see the potential of the approach.

The first NPF was a 10-year vision for Scotland but it was updated in 2011, partly in response to the Christie Commission on the Future Delivery of Public Services which sought to encourage the Scottish Government to take a more rounded approach to public policy (Christie 2011) and partly to reflect priorities as outlined in Manifesto Commitments, the Government Economic Strategy, Programme for Government and Spending Review documents. There were some changes made to the indicators but the most significant change was the inclusion of a new National Outcome related to older people-' Our people are able to maintain their independence as they get older and are able to access appropriate support when they need it'-reflecting the demographic significance of the ageing population and the government's commitment to independent living, enablement and health and social care integration (Scottish Government 2016). 
The Carnegie UK Trust was not the only external organisation that was advocating for a rethinking of the measurement of social progress. In 2012, Oxfam Scotland published the first Humankind Index for Scotland. The index was based on a consultation process with people across Scotland in order to establish what aspects of life make a difference to them. Almost 3000 people were involved in one way or another (focus groups, community workshops, street stalls, an online survey and a YouGov poll). Their priorities were then mapped onto existing data about Scotland's population, often using the same indicators as the NPF. The researchers calculated the change in indicators between 2007/08 and 2010/11. Using this index, they found that since 2007-2008, Scotland's prosperity has increased by $1.2 \%$, meaning that according to the range of areas that people in Scotland value, Scotland appears to have become more prosperous (even if just marginally) (Oxfam Scotland 2012). The Humankind Index received significant parliamentary and press interest, including a debate on the floor of the Parliament and an evidence session to the Economy, Energy and Tourism Committee in 2012 (Scottish Parliament 2012). Since that time however there has been no further version published and few mentions by parliamentarians.

Following recommendations from external stakeholders, the Scottish Government sought to legislate for the NPF within the Community Empowerment (Scotland) Act 2015 (Wallace 2013). The Act responded to concerns that the methodology of the NPF was not adequately embedded and would be vulnerable to future changes of government. The Act requires that Scottish Ministers must determine the national outcomes that result from, or are contributed to by, public services relating to non-reserved matters. In doing so they must consult, have regard to inequalities and report on prepare and publish reports about the extent to which the national outcomes have been achieved. There is no requirement that the previous model of purpose, targets, outcomes and indicators be followed. There is therefore much flexibility as to how the national outcomes may be presented and measured.

Embedded within a broader piece of legislation, the intention to place a statutory duty on Scottish Ministers to consult on and publish National Outcomes received limited responses from consultees during the Stage 2 scrutiny of the bill. Those that did comment tended to make general calls for greater openness and transparency. UNISON Scotland were one of the few to make detailed comments: 
Scotland Performs has surface similarities to Virginia Performs but is nowhere near as extensive in terms of data or analysis. The Virginia site offers both easy to read graphics for a range of geographical and subject areas for those looking for snapshots as well as explanations/discussions of issues and extensive data for those seeking wider information or wishing to do their own analysis. Scotland Performs is not the "go to" place for data on Scotland or the delivery of its services nor has it become a source of debate or discussion. (Scottish Parliament Information and Research Service 2014, p. 13)

The Act rectifies one of the criticisms of earlier iterations of the NPF (Wallace 2013) by requiring consultation on the National Outcomes stating that Scottish Ministers must consult:

i. Such persons who appear to them to represent the interests of communities in Scotland and;

ii. Such other persons as they consider appropriate.

The legislation does not stipulate the groups to be consulted. There were Stage 2 amendments to the Bill by Scottish Labour to put groups such as children's organisations on the face of the Bill, these were not passed, in part due to the restricted nature of the list presented.

As a result of the Act the Scottish Government did consult more widely on the revised National Outcomes:

- A series of public discussions facilitated by the Carnegie UK Trust involving 215 people;

- Street stalls run by Oxfam Scotland which engaged 300 people; and

- Engagement with 102 children through the Children's Parliament.

The findings were combined with earlier findings from the Fairer and Healthier Scotland conversations conducted in 2015 and 2016. These were extensive public engagement exercises which asked what a fairer, more equal Scotland would look like (Fairer Scotland) and what a healthier Scotland would look like (Healthier Scotland). Both exercises comprised substantial public engagement, involving more than 16,000 participants at public events and reaching more than 40,000 people online through social media, websites blogs and other platforms. There were also activities to engage with civil servants, other public sector organisations and the third sector. 
The refresh was overseen and informed by the NPF Roundtable. Derek Mackay, Cabinet Secretary for Finance and Constitution, chairs the Roundtable with members from across the political parties in Scotland and non-governmental organisations (Carnegie UK Trust, Oxfam Scotland, Scottish Trade Union Congress, Confederation of Scottish Local Authorities, Scottish Human Rights Commission, Scottish Environment LINK and the Scottish Local Government Partnership).

\section{COMPONENTS}

The 2018 framework has been streamlined, removing the Purpose Targets (which were often criticised for a heavy economic focus). The new framework consists of:

- Our Purpose: To focus on creating a more successful country, with opportunities for all of Scotland to flourish through increased wellbeing, and sustainable and inclusive economic growth.

- Our Values: We are a society which treats all our people with kindness, dignity, compassion and respect, and acts in an open and transparent way.

- National Outcomes:

- We have a globally competitive, entrepreneurial, inclusive and sustainable economy

- We respect, protect and fulfil human rights and live free from discrimination

- We are open, connected and make a positive contribution internationally

- We tackle poverty by sharing opportunities, wealth and power more equally

- We live in communities that are inclusive, empowered, resilient, and safe

- We grow up loved, safe and respected so that we realise our full potential

- We are well educated, skilled and able to contribute to society

- We have thriving and innovative businesses, with quality jobs and fair work for everyone

- We are healthy and active

- We value, enjoy, protect and enhance our environment

- We are creative and our vibrant and diverse cultures are expressed and enjoyed widely.

- 81 National Indicators (see Table 3.2). 
Table 3.2 The national indicators for Scotland

\begin{tabular}{|c|c|c|}
\hline Material conditions & Quality of life & Environment \\
\hline $\begin{array}{l}\text { Businesses (number, } \\
\text { objective) }\end{array}$ & $\begin{array}{l}\text { A positive experience for } \\
\text { people coming to Scotland (\%, } \\
\text { subjective) }\end{array}$ & $\begin{array}{l}\text { Sustainability of fish } \\
\text { stocks (objective) }\end{array}$ \\
\hline $\begin{array}{l}\text { Skills under-utilisation } \\
(\%, \text { objective })\end{array}$ & $\begin{array}{l}\text { Access to superfast broadband } \\
(\%, \text { objective })\end{array}$ & $\begin{array}{l}\text { Natural capital } \\
\text { (index, objective) }\end{array}$ \\
\hline $\begin{array}{l}\text { Unmanageable debt } \\
(\% \text {, subjective })\end{array}$ & $\begin{array}{l}\text { Attendance at cultural events } \\
\text { or places }(\%, \text { objective })\end{array}$ & $\begin{array}{l}\text { Carbon footprint } \\
\text { (number, objective) }\end{array}$ \\
\hline $\begin{array}{l}\text { Entrepreneurial activity } \\
\text { (index, objective) }\end{array}$ & $\begin{array}{l}\text { Child social and physical devel- } \\
\text { opment }(\% \text {, objective })\end{array}$ & $\begin{array}{l}\text { Greenhouse gas emissions } \\
\text { (number, objective) }\end{array}$ \\
\hline $\begin{array}{l}\text { Persistent poverty } \\
(\%, \text { objective })\end{array}$ & $\begin{array}{l}\text { Children have positive rela- } \\
\text { tionships }(\%, \text { subjective) }\end{array}$ & $\begin{array}{l}\text { Marine environment } \\
(\%, \text { objective })\end{array}$ \\
\hline Exporting $(£$, objective $)$ & $\begin{array}{l}\text { Confidence of children and } \\
\text { young people ( } \% \text {, subjective })\end{array}$ & $\begin{array}{l}\text { Energy from renewable } \\
\text { sources }(\%, \text { objective) }\end{array}$ \\
\hline Cost of living (\%, objective) & $\begin{array}{l}\text { Crime victimisation } \\
(\%, \text { objective })\end{array}$ & $\begin{array}{l}\text { State of historic sites } \\
(\%, \text { objective })\end{array}$ \\
\hline $\begin{array}{l}\text { High growth businesses } \\
\text { (number, objective) }\end{array}$ & $\begin{array}{l}\text { Educational attainment } \\
(\%, \text { objective })\end{array}$ & $\begin{array}{l}\text { Journeys by active travel } \\
(\%, \text { objective })\end{array}$ \\
\hline $\begin{array}{l}\text { Productivity (index, } \\
\text { objective) }\end{array}$ & $\begin{array}{l}\text { Engagement in extra-curricular } \\
\text { activities (\%, objective) }\end{array}$ & $\begin{array}{l}\text { Biodiversity (index, } \\
\text { objective) }\end{array}$ \\
\hline $\begin{array}{l}\text { Gap in male and female } \\
\text { employment (\%, objective) }\end{array}$ & $\begin{array}{l}\text { Health risk behaviours (index, } \\
\text { objective) }\end{array}$ & $\begin{array}{l}\text { Condition of protected } \\
\text { nature sites }(\% \text {, objective })\end{array}$ \\
\hline $\begin{array}{l}\text { Relative poverty after } \\
\text { housing costs }(\% \text {, objective })\end{array}$ & $\begin{array}{l}\text { Healthy life expectancy (years, } \\
\text { objective) }\end{array}$ & $\begin{array}{l}\text { Access to green and blue } \\
\text { space }(\%, \text { objective })\end{array}$ \\
\hline $\begin{array}{l}\text { Food insecurity } \\
\text { (in development) }\end{array}$ & Healthy start (\%, objective) & $\begin{array}{l}\text { Waste generated (number, } \\
\text { objective) }\end{array}$ \\
\hline $\begin{array}{l}\text { Employees on the living } \\
\text { wage (\%, objective) }\end{array}$ & Healthy weight $(\%$, objective $)$ & $\begin{array}{l}\text { Visits to the outdoors } \\
(\%, \text { objective })\end{array}$ \\
\hline $\begin{array}{l}\text { Innovative businesses } \\
(\%, \text { objective })\end{array}$ & $\begin{array}{l}\text { Influence over local decisions } \\
(\% \text {, subjective })\end{array}$ & \\
\hline $\begin{array}{l}\text { International networks } \\
\text { (in development) }\end{array}$ & Loneliness (\%, subjective) & \\
\hline $\begin{array}{l}\text { Spend on research and } \\
\text { development }(£ \text {, objective })\end{array}$ & $\begin{array}{l}\text { Mental wellbeing (index, } \\
\text { subjective) }\end{array}$ & \\
\hline $\begin{array}{l}\text { Gender pay gap }(\%, \\
\text { objective) }\end{array}$ & $\begin{array}{l}\text { Participation in a cultural } \\
\text { activity }(\%, \text { subjective })\end{array}$ & \\
\hline $\begin{array}{l}\text { Employee voice (\%, } \\
\text { objective) }\end{array}$ & $\begin{array}{l}\text { Perception of access to justice } \\
(\%, \text { subjective })\end{array}$ & \\
\hline $\begin{array}{l}\text { Growth in cultural economy } \\
(\%, \text { objective })\end{array}$ & $\begin{array}{l}\text { Perception of crime rate } \\
(\%, \text { subjective })\end{array}$ & \\
\hline $\begin{array}{l}\text { Scotland's reputation (index, } \\
\text { objective) }\end{array}$ & $\begin{array}{l}\text { Perception of local area } \\
(\%, \text { subjective })\end{array}$ & \\
\hline $\begin{array}{l}\text { Income inequalities (ratio, } \\
\text { objective) }\end{array}$ & Physical activity (\%, objective) & \\
\hline
\end{tabular}


Table 3.2 (continued)

\begin{tabular}{|c|c|c|}
\hline Material conditions & Quality of life & Environment \\
\hline $\begin{array}{l}\text { Contribution of devel- } \\
\text { opment support to other } \\
\text { nations }(£, \text { objective })\end{array}$ & \multicolumn{2}{|l|}{ Places to interact $(\%$, objective $)$} \\
\hline $\begin{array}{l}\text { Gender balance in organisa- } \\
\text { tions (\%, objective) }\end{array}$ & \multicolumn{2}{|l|}{$\begin{array}{l}\text { Premature mortality rate } \\
\text { (number, objective) }\end{array}$} \\
\hline $\begin{array}{l}\text { Children's material depriva- } \\
\text { tion (\%, objective) }\end{array}$ & \multicolumn{2}{|l|}{$\begin{array}{l}\text { Public services treat people } \\
\text { with dignity and respect } \\
(\%, \text { subjective })\end{array}$} \\
\hline $\begin{array}{l}\text { Wealth inequalities } \\
(\%, \text { objective })\end{array}$ & \multicolumn{2}{|l|}{$\begin{array}{l}\text { Quality of care experience } \\
(\%, \text { subjective })\end{array}$} \\
\hline $\begin{array}{l}\text { Economic participation } \\
(\%, \text { objective })\end{array}$ & \multicolumn{2}{|l|}{$\begin{array}{l}\text { Quality of children's services } \\
(\% \text { objective })\end{array}$} \\
\hline $\begin{array}{l}\text { Skill shortage vacancies } \\
(\%, \text { objective })\end{array}$ & \multicolumn{2}{|l|}{ Quality of public services } \\
\hline $\begin{array}{l}\text { Land ownership } \\
(\%, \text { objective })\end{array}$ & and young people & \\
\hline $\begin{array}{l}\text { People working in arts and } \\
\text { culture }(\% \text {, objective) }\end{array}$ & \multicolumn{2}{|l|}{ Satisfaction with housing } \\
\hline $\begin{array}{l}\text { Contractually secure work } \\
(\%, \text { objective })\end{array}$ & \multicolumn{2}{|l|}{ Scotland's population } \\
\hline & \multicolumn{2}{|l|}{ Skills profile of the population } \\
\hline & \multicolumn{2}{|l|}{ Social capital (in development) } \\
\hline & \multicolumn{2}{|l|}{ Trust in public organisations } \\
\hline & \multicolumn{2}{|l|}{$(\%$, subjective $)$} \\
\hline & \multicolumn{2}{|l|}{$(\%$, objective $)$} \\
\hline & \multicolumn{2}{|l|}{ Work related ill health } \\
\hline & \multicolumn{2}{|l|}{$(\%$, objective $)$} \\
\hline & \multicolumn{2}{|l|}{$\begin{array}{l}\text { Young people's participation } \\
(\% \text {, subjective })\end{array}$} \\
\hline & \multicolumn{2}{|l|}{ Child wellbeing and happiness } \\
\hline & \multicolumn{2}{|l|}{$(\%$, subjective $)$} \\
\hline & \multicolumn{2}{|l|}{ Children's voices } \\
\hline & \multicolumn{2}{|l|}{$(\%$, subjective $)$} \\
\hline $\begin{array}{l}\text { Total 30: } 27 \text { objective, } 1 \\
\text { subjective, } 2 \text { in development }\end{array}$ & $\begin{array}{l}\text { Total 38: } 18 \text { objective, } 18 \\
\text { subjective, } 2 \text { in development }\end{array}$ & Total 13: 13 objective \\
\hline
\end{tabular}


In a further development, each National Outcome is clearly linked to one or more of the United Nations Sustainable Development Goals. Scottish Ministers are under a duty to revise the National Outcomes at least every five years and in doing so they must consult widely.

Reports about the extent to which the National Outcomes have been achieved or not achieved must be prepared and published by the Scottish Ministers when they consider it appropriate. The report must include information on progress since the previous report; however, the format of the reporting will be for the Scottish Ministers to decide. The Scottish Government is currently testing an interactive website for communicating progress against the national indicators.

\section{Contribution}

With 10 years of experience, the Scottish experience ought to provide evidence on the impacts of a wellbeing framework. There are contradictory views on its success. Within the civil service there is a strong belief that the framework has been transformative. But for others the scale of the change sought has not been realised.

This section explores whether there is evidence to suggest that the NPF has contributed to advocacy, policy or social change against the six categories of change identified by previous research as potential benefits of a wellbeing framework (narratives, horizontal integration, vertical integration, participation, prevention and budgeting).

\section{A New Narrative on Wellbeing}

The language of the original purpose statement was intentional. It talked of Scotland 'flourishing'. In doing so the Scottish Government was alluding to wider conversations about social progress. However messages were clearly focused on public services and at accountability to the public for good governance. The first press release for Scotland Performs (the website that was used to present the outcomes and indicators from 2008 to 2018) cites that aim as 'to track the success of the Scottish Government's objectives of making the country wealthier, safer, healthier, greener and smarter' (The Scotsman 2008). The focus on government activity, rather than the wellbeing of the people more widely, was reinforced by the 2015 legislation which relates the National Outcomes to the activities on public services, and only on devolved matters. 
As the framework has developed and established more focus on sustainable development, a consistent message from non-governmental organisations has been that the purpose statement was too focused on economic growth (Oxfam Scotland/Scottish Environment Link/ STUC 2017). In the 2018 iteration, the purpose statement has been retitled from 'The Government's Purpose' to 'Our Purpose' to better reflect views that it should belong to all of Scotland, and to ensure all sectors (public, private and voluntary) can unite behind it. In addition, the Purpose has been slightly rephrased to reflect the commitment to a 'sustainable and inclusive economy' an alongside the aim to improve the 'wellbeing' of all Scotland's people. For many, this has not gone far enough, with non-governmental organisations arguing that growth of the economy can still be seen as a goal for Scotland with wellbeing separate to it, rather than the economy being subservient to wellbeing (Oxfam Scotland/Scottish Environment Link/STUC 2017).

The dominant view of the NPF is that it has not received the attention that it deserves. It is therefore useful to cross-check this perception against evidence. As the target is at least in part to improve accountability, scrutiny and decision-making, the mentions in the Scottish Parliament are a useful barometer of the extent to which the approach is embedded in these processes. Between 1 January 2007 and 31 March 2018 there were 615 separate references to the NPF in the official report of the Scottish Parliament. Of these, almost 200 were in debates or committee meetings that referred to the NPF only once or twice. If we remove these, in the 10 years of the NPF there were 61 substantial discussions of the NPF in the Scottish Parliament (including committee meetings).

Of these, 10 were during Parliamentary debates. At the Committee level, the committee most likely to refer to the NPF in debate was the Finance Committee (17 times). The Environment Committee referred to the NPF substantially in eight meetings (five during the 2011-2016 session when it was called the Transport, Infrastructure and Climate Change Committee then the Rural Affairs, Climate Change and Environment Committee, and three times in the current session when the Committee is known as the Environment, Climate Change and Land Reform Committee). The Education Committee has referred to it substantially only four times in ten years and the Health Committee only once.

Moreover, this analysis shows the development over time of the interest in the NPF. During the 2007-2011 parliamentary session, there were 
no debates that referred to the framework more than twice during the main Plenary session of the Parliament. From 2011 to 2016 there were nine debates that referenced the framework more than three times during the debate.

This metric is admittedly superficial but it is instructive in a number of ways. Firstly, it is simply incorrect to suggest that there is no parliamentary interest or awareness of the NPF. Use of the NPF in debate is widespread, as a source of evidence or as a debating topic in its own right around the mechanisms for holding government to account or in terms of openness and transparency. Secondly, the analysis provides further evidence that the approach is linked strongly to public sector reform and this is the overriding purpose in the minds of parliamentarians. Its use in environmental debates is less apparent. But more tellingly, it provides evidence of the limits of the tool. Where Scotland's professions are strongest, in education and health, the NPF is of limited interest and use.

\section{Horizontal Integration}

In 2007-2008 when the NPF was being implemented, several related organisational changes were also put in place. To mirror the smaller Cabinet of the minority SNP government, the Scottish civil service was restructured to have a smaller number of Director-Generals (currently six) and Directors underneath this level (currently 30). The aim of the changes was to build collective responsibility for performance across the government and public sector.

The Director-Generals are responsible for a number for Directorates with coherent themes, so for example, as one would expect, the Director-General for Education, Communities and Justice is responsible for the Learning Directorate and the Housing and Social Justice Directorate (among others). But these areas of responsibility are broader than the traditional UK civil service structure. And they are charged not just with making the connections between Directorates that they have responsibility for, but also making connections across portfolios held by other Director-Generals.

The NPF approach was well received by the civil service, providing them with an opportunity to shift their own work towards outcomes and contribute to meaningful, and lasting, change for Scotland. Within this general positive approach though, the implementation was dependent on the leadership within Directorates. In areas where 
implementation moved quickly (e.g. in Justice) there was a clearly identifiable leader at Director-General or Director level. The Scottish Government reports that it has made an explicit policy of recruiting open and collaborative leaders into the civil service who can see beyond their immediate area of responsibility and situate themselves and their work against a wider set of outcomes for all of society as set out in the NPF (Menzies 2017).

The structural changes at Director-General level clearly had an impact through a smaller and tighter senior civil service. But leadership was also shown at Director level, and hence more clearly focused on a specific policy area. A clear vision of the role of the service or sector was required prior to engaging in integrated working with other parts of the public sector.

The operational activity for the NPF is carried out by the Performance Unit, within the Office of the Chief Statistician and Performance. This unit is a mixed team of statisticians and policy professionals, linking the data analysis to the policy intention and promoting the framework across the government. The team is located within the government and as such is not an independent statistical unit. As part of the implementation of the NPF 'outcome leaders' were established with one 'leader' per national outcome. This enabled sharing of information across Directorates, when more than one is contributing to an outcome.

Since implementation in 2007, the NPF has influenced policy development across the central civil service. The Scottish Government reports that there are now several aligned frameworks which link to the National Outcomes:

- Active Scotland

- Commonwealth Games 2014

- Housing and Regeneration

- Justice

- Procurement

The use of the National Outcomes as a 'hook' by those seeking to influence policy has developed significantly, for example the Commission on Housing and Wellbeing (2015) the National Library Strategy (Scottish Library and Information Council 2015) and the Legal Aid Review (Evans 2018) all placed their recommendations within the context of the 
national outcomes. A case study on the revised approach to Justice is set out to explore how this works in practice.

\section{Case study: Rethinking Justice}

It is difficult to attribute general trends to specific policy changes but the Scottish example comes close in providing a coherent story around the impact of the reforms to the justice system. The Directorate took a strong evidence-based approach to rethinking justice. This confirmed the need for early and targeted intervention to prevent offending and to reduce reoffending. While the Justice Division was 'responsible' for offending and reoffending rates, it was clear from this work that improving links between the justice system and other public services such as housing and employment would be critical to their success.

The process was one of dialogue within the Justice Division and with colleagues in other Divisions and public bodies. As one source told me: 'the indicators in the Justice dashboard were developed through a change process that everyone had signed up to; so there was real change in relationships and how people interacted with each other, in how business was done.'

The average number of reconvictions per offender has decreased by $17 \%$ in the past decade. This fall has been driven significantly by those aged 25 and under, with average reconvictions falling by $20 \%$ for under 21 year olds and by $26 \%$ for the $21-25$ age group (Scottish Government 2017). The Scottish Government analytical teams are cautious about attributing this change directly to the change in government approach. As a comparison, the adult reoffending rate for England has decreased by less than one percentage point since 2005 (UK Ministry of Justice 2018).

However, despite these examples, alignment is not complete and there remain many examples of policies that do not take account of the NPF. Health and social care in particular has a complex landscape of accountability structures with legislative and policy targets and outcomes woven through multiple layers of administration. There are currently three sets of indicators that are used to assess the performance of health and social care services in Scotland: 
- The NPF indicators (81 indicators set out in Table 3.2, of which 13 have a direct relationship to health and social care).

- Local Delivery Plan indicators and standards (19 indicators which are largely objective indicators including cancer detection rates, waiting times, the treatment time guarantee, referral to treatment times).

- Health and Social Care Integration Indicators (23 indicators which are a mix of subjective assessments including ability to look after one's own health, living independently, having a say in one's care and objective data such as premature mortality rate, staff satisfaction rates, emergency admissions and readmission rate).

As Harry Burns notes in his review of targets and indicators in Scottish health and social care: 'the present system of targets and indicators is fragmented and many of the indicators do not lend themselves to effective improvement interventions' (Burns 2017, p. 30). This was continued even after the most recent update to the NPF where two days later a set of priorities for public health were issued by the Scottish Government (2018c).

There is other evidence of a lack of alignment with the achievements noted by education and planning in relation to the NPF tending towards inputs and processes, while others report on programme level impacts rather than impacts on society as a whole (Scottish Government 2017).

Further, there is no clear articulation from the Scottish Government of how the National Outcomes, and indicators, should relate to the performance management of specific programmes or services.

\section{Vertical Integration}

The SNP government that came to power in 2007 also had in its sights a new relationship with local government. It established a Concordat between Scottish and local government which set out a new, mature relationship between Scottish and local government (Scottish Government/ COSLA 2012). It secured a reduction in ring-fencing, monitoring and scrutiny for local government in return for Single Outcome Agreements which bind local authorities (originally local councils but now through joint Community Planning Partnerships (CPPs)) within overall government outcomes (through the NPF) but also taking account of local priorities. While the new relationship between Scottish and local 
government was initially perceived relatively positively, as time has gone on it has become more problematic. Some commentators have drawn attention to the Concordat's limitations and the lack of willingness of the Scottish Government to tackle some of the more difficult issues around localism, such as a lack of community engagement (Osborne et al. 2012; Blackburn and Keating 2012).

The Community Empowerment (Scotland) Act 2015 gives statutory purpose to community planning for the first time and places a duty on CPPs to produce and publish a local outcomes improvement plan (LOIP) and a locality plan which identifies the local authority sub-areas which are experiencing the poorest outcomes and outlines both the action proposed and the timescale for improving outcomes at the local area. The Improvement Service, NHS National Services Scotland and NHS Health Scotland worked with a small number of CPPs to develop their LOIP, which CPPs were required to have in place and approved by 1 October 2017 . The LOIPs published demonstrate the priority outcomes of different local authorities.

The Scottish Government has continued its work to join up public services at a local level through the Public Bodies (Joint Working) (Scotland) Act 2014 which established Integration Authorities to plan and deliver health and social care services for their area under the management of Integration Joint Boards. While the policy goals are to develop seamless services, at a service level, the proliferation of measures and indicators for different purposes is problematic. Children in Scotland reported that of the performance coordinators they interviewed in research on health and social care integration estimated that they were already aware of over 400 measures and indicators that had to be recorded and reported for a combination of local and national monitoring (Stephen et al. 2015).

Away from this administrative complexity that the system has created, there are calls for greater powers for local government in Scotland. The concordat may have stabilised relationships between Scottish and local government for a time but it did not resolve the central issue of the correct balance between powers between the tiers of democracy in Scotland. The Commission on Local Government concluded that:

relying on national governments for direction and funding has contributed to a feeling that local government is accountable up to the centre, rather than out to its communities... That the Scottish Parliament is in exactly 
the same position with respect to Westminster illustrates how 'top down' the whole framework of democracy is. (Commission on the Future of Local Democracy 2014, p. 8)

The Commission identified improving wellbeing as the goal for local government but not draw any connection between this and the wellbeing framework.

The Scottish Government is currently carrying out a Local Governance Review which will consider how powers, responsibilities and resources are shared across national and local spheres of government, and with communities. The first phase is focusing on communities alone and so it is too early to assess whether the wellbeing framework has had any influence here.

\section{Participation}

The NPF did not start from a strong position on participation. The development of indicators was seen as a technocratic exercise, the choice of outcomes, a political one. Only slowly, and with considerable lobbying from non-governmental organisations, did it develop a sense of the importance of citizen participation for the framework to have legitimacy (Wallace 2013).

This is emblematic of a larger issue in Scottish life around renewing democracy and civil society. A number of initiatives are underway to encourage greater conversation and debate between the people of Scotland and decision-makers. These include travelling Cabinet meetings, where Cabinet meets in different towns and cities across Scotland, followed by a live-streamed public meeting; and Experience Panels involving people who have directly encountered the benefits system to have a role in shaping Scotland's new social security power (Menzies 2017).

Potentially more transformative is the growing use of participatory budgeting by local authorities. Agreement was reached with COSLA that at least $1 \%$ of local government budgets will be subject to participatory budgeting by the end of 2021 , giving communities more influence than ever to make decisions on how funding is spent in their localities; giving tens of thousands of people a say in how almost $£ 100 \mathrm{~m}$ will be spent (Scottish Government 2017).

The National Outcomes do not refer explicitly to democracy, though the values statement does refer to being 'open'. The measurements 
selected include influence over local decisions and trust in public organisations, but the Scottish Government did not include the common international indicator of voting levels for Scottish Government or local government elections (despite it performing well internationally on this). It is not entirely clear therefore what the view of the Scottish Government, through the NPF is of democracy as a component of wellbeing, and there is limited evidence of any direct contribution from the NPF to participation in democracy.

There are however reasons for optimism, one area where the 2018 NPF has strengthened its approach is the importance it has placed on children and young people's voice which is actively measured and promoted.

\section{Prevention}

The Scottish Government has committed to 'a decisive shift towards prevention' (Scottish Government 2011) as a response to the Christie Commission on the Future Delivery of Public Services reform which concluded:

The adoption of preventative approaches, in particular approaches which build on the active participation of service users and communities, will contribute significantly to making the best possible use of money and other assets. They will help to eradicate duplication and waste and, critically, take demand out of the system over the longer term. (Christie 2011, para. 6.8)

Reflecting on this significance Sir John Elvidge notes that the drivers for a new early years strategy actually came from Scotland's poor record on offending and reoffending. Rather than seeing this as a justice issue, the approach taken was to focus on what were seen as the root causes of offending: poverty and adverse childhood experiences.

Here the Scottish Government took an improvement science approach to improving outcomes through the Early Years Collaborative (EYC). Heavily influenced by health improvement science, the EYC was established in 2012 as a multi-agency platform to improve outcomes for children and families. This was specifically linked to the National Outcome that Scotland be 'the best place in the world to grow up' but the group identified their own indicators (based on the proportion reaching developmental milestones, which is now included in the revised 2018 indicator set). 
In many discussion papers, prevention becomes inextricably linked to interventions in the early years of a child's life, focusing on life stages rather than prevention across the life course. The interpretation of prevention as relating to life course can reinforce silo approaches, making prevention the responsibility of specific services, rather than a more transformative, cross-cutting approach.

One example where we can see a shift to prevention cited by the Scottish Government is the youth employment strategy (Developing the Young Workforce) which aims to reduce youth unemployment levels by $40 \%$ by 2021 . It is explicitly referred to as early intervention on youth unemployment. The strategy provides work-relevant education to young people, giving them appropriate skills for the current and anticipated jobs market. It does this by:

- Creating new vocational learning options

- Enabling young people to learn in a range of settings in their senior phase of school

- Embedding employer engagement in education

- Offering careers advice at an earlier point in school

- Introducing new standards for careers guidance and work experience (Scottish Government 2017).

Through this approach, the Scottish Government achieved their target by May 2017, four years earlier than planned. Scotland's youth unemployment rate is currently $9.8 \%$, lower than the $11.3 \%$ rate in the UK as a whole (Scottish Government 2018b). That this example is cited in an evidence report on the impact of the NPF shows that there are links made between this strategy and the indicators on youth unemployment. But it is telling that the focus is on a target developed from the NPF rather than continuous improvement in the indicators.

While the aspirations are clear in policy development, few stakeholders report that there has been a shift in behaviours (or funding). As Paul Cairney notes in his analysis of prevention in Scottish public policy, the lack of clarity over the meaning of prevention and early intervention allows CPPs to fit much of their current services under that heading, some have even replaced the Scottish Government definition with their own within their Single Outcome Agreement (Cairney 2016). 


\section{Budgeting}

As noted earlier, one of the key drivers was the work of the influential Finance Committee in the second Parliamentary Session (2003-2007). However, it was not until 2014 that the NPF was formally reported to the Scottish Parliament as part of the Budget scrutiny process. Initially it was argued that the Scotland Performs website which hosts the indicator data was publicly available and thus accessible to any committee of the Scottish Parliament. But the Committees themselves asked for tailored reports covering their areas of interest. The Performance Unit therefore began preparing Performance Scorecards for each Committee of the Scottish Parliament to review as part of their scrutiny of the budget. These Scorecards summarise the trends in indicators and show whether performance is improving, maintaining or worsening. In the second iteration of the Scorecards, the Performance Unit also provided an accompanying report setting out the inter-dependency of indicators and outcomes, rectifying concerns that the Committee structure was diluting the whole-of-government approach of the framework.

There was generally positive feedback on the Scorecards, however in 2017 the Finance and Constitution Committee reported:

Despite this new performance-based approach the budget process has remained largely iterative and forward looking. The focus tends to be on examining the Scottish Government's expenditure proposals for the following year. There is little scrutiny of budget decisions at a strategic level including whether the Scottish Government is making any progress against its declared objectives. (Scottish Parliament Finance Committee 2017, p. 1)

Similar criticisms are made by the Scottish Council on Development and Industry and the Scottish Chambers of Industry (Scottish Parliament Finance Committee 2013).

This is despite significant efforts made by Audit Scotland to move public bodies to what it calls 'priority-based budgeting' which focuses on the delivery of priority outcomes and allocates money to those services or areas which make the greatest contribution to delivering these outcomes. Audit Scotland goes on to note that 'this approach means services or activities which contribute least to outcomes may be reduced or withdrawn' (Audit Scotland 2011, para. 68). Disinvestment, simply stopping doing things that do not contribute to wellbeing outcomes, has proved to be the most difficult part of the process. 


\section{Conclusion}

The Scottish experience on wellbeing frameworks provides some evidence of the link between a wellbeing framework and advocacy, policy and social change. Its key strength remains within its origins, as a whole-of-government approach for the Scottish Government, operating at the horizontal level. The success of the tool for vertical integration has been hampered by the number of competing initiatives which affect local services in unpredictable ways.

The framework itself has been significantly improved in the 2018 refresh and now more clearly states the connection with sustainable development and a vision for Scotland as a whole. It has evolved from its earlier internal performance management framework. The journey towards more environmental focus and citizen participation has required the active involvement of non-governmental organisations. There remains a central question of whether the framework is a government framework for public services or a vision for the future of Scotland.

\section{REFERENCES}

Audit Scotland. (2011). Scotland's Public Finances: Addressing the Challenges. Edinburgh: Audit Scotland.

Blackburn, L., \& Keating, M. (2012). Scottish Policy Innovation Forum: Localism and Local Governance. Scottish Affairs, 81, 98-109.

Burns, H. (2017). Targets and Indicators in Health and Social Care: A Review. Edinburgh: Cosla/Scottish Government.

Cairney, P. (2016). Early Intervention Policy, from 'Troubled Families' to 'Named Persons': Problems with Evidence and Framing 'Valence' Issues [Online]. Available at: https://paulcairney.wordpress.com/tag/early-years-collaborative/. Accessed June 2018.

Christie, C. (2011). Report on the Future Delivery of Public Services by the Commission Chaired by Dr Campbell Christie. Edinburgh: Scottish Government.

Commission on Housing and Wellbeing. (2015). A Blueprint for Scotland's Future. Edinburgh: Commission on Housing and Wellbeing.

Commission on the Future of Local Democracy. (2014). Effective Democracy: Reconnecting with Communities. Edinburgh: Commission on the Future of Local Democracy.

Elvidge, J. (2011). Northern Exposure: Lessons from the First Twelve Years of Devolved Government in Scotland. London: Institute for Government. 
Evans, M. (2018). Rethinking Legal Aid: An Independent Strategic Review. Edinburgh: Scottish Government.

Kellas, J. G. (1989). Prospects for a New Scottish Political System. Parliamentary Affairs, 45(3), 519-532.

Menzies, R. (2017). From a Shared Vision to Inclusive Implementation: Innovative Approaches to Developing Government Frameworks on Wellbeing. Dunfermline: Carnegie UK Trust.

Mooney, G., \& Scott, G. (2012). Social Justice and Social Policy in Scotland. Bristol: Policy Press.

Osborne, S., et al. (2012). The Opportunities and Challenges of the Changing Public Services Landscape for the Third Sector in Scotland: A Longitudinal Study Year Three Report. Edinburgh: Scottish Government.

Oxfam Scotland. (2012). Oxfam Humankind Index: The New Measure of Scotland's Prosperity, Second Results. Oxford: Oxfam, GB.

Oxfam Scotland/Scottish Environment Link/STUC. (2017). Briefing on the National Performance Framework [Online]. Available at: http://www.scotlink.org/wp/files/documents/NPF-briefing-Jan-2017-2.pdf. Accessed Apr 2018 .

The Scotsman. (2008). New Website Shows Off Our Vital Statistics [Online]. Available at: https://www.scotsman.com/news/politics/new-website-showsoff-our-vital-statistics-1-1261747. Accessed June 2018.

Scottish Government. (2011). Renewing Scotland's Public Services-Priorities for Reform in Response to the Christie Commission. Edinburgh: Scottish Government.

Scottish Government. (2016). About the NPF [Online]. Available at: http://www. gov.scot/About/Performance/scotPerforms/NPFChanges. Accessed 2018.

Scottish Government. (2017). Scotland Performs Update. Edinburgh: Scottish Government.

Scottish Government. (2018a). A Vision for National Wellbeing [Online]. Available at: https://news.gov.scot/news/a-vision-for-national-wellbeing. Accessed June 2018.

Scottish Government. (2018b). Scotland's Labour Market-Tables and Charts. Edinburgh: Scottish Government.

Scottish Government. (2018c). Scotland's Public Health Priorities. Edinburgh: Scottish Government.

Scottish Government/COSLA. (2012). Review of Community Planning and Single Outcome Agreement. Edinburgh: Scottish Government.

Scottish Library and Information Council. (2015). Ambition and Opportunity: A Strategy for Public Libraries in Scotland 2015-2020. Edinburgh: Scottish Library and Information Council. 
Scottish Parliament. (2012). Official Report: Meeting of the Parliament 05 September 2012 [Online]. Available at: http://www.parliament.scot/parliamentarybusiness /report.aspx $\mathrm{r}=7524 \& \mathrm{i}=68637 \& \mathrm{c}=0 \& \mathrm{~s}=$ humankind. Accessed 2018.

Scottish Parliament Finance Committee. (2000). Finance Committee Report on Stage 1 of the 2001/02 Budget Process. Edinburgh: Scottish Parliament.

Scottish Parliament Finance Committee. (2007). Session 2 Legacy Paper. Edinburgh: Scottish Parliament.

Scottish Parliament Finance Committee. (2013). Agenda and Papers 24th Meeting 2013 [Online]. Available at: http://www.parliament.scot/S4_ FinanceCommittee/papers_2october.pdf. Accessed Feb 2018.

Scottish Parliament Finance Committee. (2017). Guidance to Subject Committees. Edinburgh: Scottish Parliament.

Scottish Parliament Information and Research Service. (2014). Local Government and Regeneration Committee: Community Empowerment (Scotland) Bill Summary of Responses. Edinburgh: Scottish Parliament Information and Research Service.

Stephen, J., Lerpiniere, J., Young, E., \& Welch, V. (2015). Integrating Health and Social Care in Scotland: Potential Impact on Children's Services. Edinburgh: Children in Scotland.

Stiglitz, J., Sen, A., \& Fitoussi, J.-P. (2009). Report by the Commission on the Measurement of Economic Performance and Social Progress [Online]. Available at: www.stiglitz-sen-fitoussi.fr.

UK Ministry of Justice. (2018). Proven Reoffending Statistics Quarterly Bulletin: January to March 2016. London: UK Ministry of Justice.

Wallace, J. (2013). Shifting the Dial in Scotland. Dunfermline: Carnegie UK Trust. 
Open Access This chapter is licensed under the terms of the Creative Commons Attribution 4.0 International License (http://creativecommons.org/licenses/ by $/ 4.0 /$ ), which permits use, sharing, adaptation, distribution and reproduction in any medium or format, as long as you give appropriate credit to the original author(s) and the source, provide a link to the Creative Commons license and indicate if changes were made.

The images or other third party material in this chapter are included in the chapter's Creative Commons license, unless indicated otherwise in a credit line to the material. If material is not included in the chapter's Creative Commons license and your intended use is not permitted by statutory regulation or exceeds the permitted use, you will need to obtain permission directly from the copyright holder.

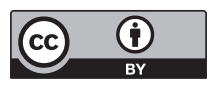

